\title{
Symptoms and yield loss caused by rice stripe mosaic virus
}

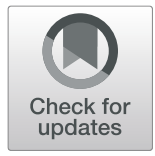

\author{
Siping Chen, Weilin Li, Xiuqin Huang, Biao Chen, Tong Zhang and Guohui Zhou*
}

\begin{abstract}
Background: Rice stripe mosaic virus (RSMV) is a tentative new Cytorhabdovirus species in family Rhabdoviridae transmitted by the leafhopper Recilia dorsalis. Although the virus was first detected in southern China in 2015, few studies have investigated rice symptoms and yield losses caused by RSMV infection.

Methods: In this study, we observed and systematically compared symptoms of three virally infected, representative varieties of indica, hybrid and japonica rice and determined the yield parameters of the artificially inoculated plants.

Results: The three RSMV-infected cultivated rice varieties exhibited slight dwarfing, striped mosaicism, stiff, crinkled or even twisted leaves, an increased number of tillers, delayed heading, cluster-shaped shortening of panicles and mostly unfilled grains. Slight differences in symptom occurrence time were observed under different environmental conditions. For example, mosaic symptoms appeared earlier and crinkling symptoms appeared later, with both symptoms later receding in some infected plants. Yield losses due to RSMV also differed among varieties. The most serious yield reduction was experienced by indica rice (cv. Meixiangzhan), followed by hybrid indica rice (cv. Wuyou 1179) and then japonica (cv. Nipponbare). Single panicle weight, seed setting rate and 1000-kernel weight were reduced in the three infected varieties compared with healthy plants-by 85.42, 94.85 and $31.56 \%$ in Meixiangzhan; 52.43, 53.06 and 25.65\% in Wuyou 1179 and 25.53, 49.32 and 23.86\% in Nipponbare, respectively.
\end{abstract}

Conclusions: Our findings contribute basic data for field investigations, formulation of prevention and control strategies and further study of the pathogenesis of RSMV.

Keywords: Rice viral disease, Rice stripe mosaic virus, Symptomology, Yield loss assessment

\section{Background}

Rice (Oryza sativa) is one of the world's major cereal food crops. Rice production is seriously threatened by viral diseases [1], which have become an important problem. As many as 17 rice viruses, widely distributed in rice production areas of Asia and Africa, have been reported. Most of these viruses are transmitted by insects and cause intermittent outbreaks [2-4].

Rice stripe mosaic virus (RSMV) is a tentative new species first detected in southern China in 2015. RMSV is the first reported Cytorhabdovirus (family Rhabdoviridae) transmitted by the leafhopper Recilia dorsalis and the first to infect rice. Previous research has shown that the virus is widely distributed in southern China, where

\footnotetext{
* Correspondence: ghzhou@scau.edu.cn

Key Laboratory of Microbial Signals and Disease Control of Guangdong

Province, College of Agriculture, South China Agricultural University,

Guangzhou 510642, Guangdong, China
}

the incidence of infection in some fields exceeds $70 \%$ and causes serious rice production losses [2].

RSMV-infected rice is mainly characterized by slight dwarfing, the presence of twisted leaves exhibiting striped mosaicism, an increased number of tillers, inferior heading and mostly unfilled grains [2]. Although these symptoms have been reported, previous studies of RSMV have not addressed the viral disease symptom process, symptomatic differences among rice varieties or effects on yield components. In this study, we accordingly investigated RSMV symptoms and their effects on yield factors of representative indica, hybrid and japonica rice varieties (cultivars Meixiangzhan, Wuyou 1179 and Nipponbare, respectively) following artificial inoculation in an insect-proof room. Our findings can serve as a basis for disease diagnosis in the field and the formulation of control strategies.

(c) The Author(s). 2019 Open Access This article is distributed under the terms of the Creative Commons Attribution 4.0 International License (http://creativecommons.org/licenses/by/4.0/), which permits unrestricted use, distribution, and reproduction in any medium, provided you give appropriate credit to the original author(s) and the source, provide a link to the Creative Commons license, and indicate if changes were made. The Creative Commons Public Domain Dedication waiver (http://creativecommons.org/publicdomain/zero/1.0/) applies to the data made available in this article, unless otherwise stated. 


\section{Materials and methods}

\section{Rice, virus and vector insect}

Three representative rice varieties, indica rice Meixiangzhan, japonica rice Nipponbare and hybrid indica rice Wuyou 1179, were purchased from a commercial supplier (Guangdong South China Agricultural University Seeds, China). Plants infected with RSMV and $R$. dorsalis leafhoppers were collected in Luoding, Guangdong Province, China, and maintained in a greenhouse in our laboratory [5].

\section{Rice culture}

Seeds of the tested rice varieties were soaked in water for $12 \mathrm{~h}$, germinated for 2 days at $37^{\circ} \mathrm{C}$, and then sown in organic peat soil (Jiffy). The germinated seedlings were grown in a greenhouse at $28^{\circ} \mathrm{C}$ and $60 \%$ relative humidity under long-day conditions (16-h light/8-h dark) until the three-leaf stage [6]. Seedlings at the same growth stage were selected for inoculation with RSMV.

\section{Virus inoculation and detection}

Caged, late-stage nymphs of $R$. dorsalis were allowed to feed on RSMV-infected rice plants at the tillering stage for 16 days. Test seedlings of rice at the three-leaf stage were then inoculated using viruliferous (RSMV) or virus-free (mock) leafhoppers at a ratio of three insects per plant for 3 days. After removal of insects, the inoculated plants were transplanted into a round area with a diameter of $29 \mathrm{~cm}$ per plant in an insect-proof room and cultured to maturity at $25^{\circ} \mathrm{C}-30^{\circ} \mathrm{C}$ and $60-80 \%$ relative humidity under long-day conditions (16-h light/8-h dark). The experiment was carried out from April to May 2018, with three biological replicates processed independently. At least 30 plants per rice variety were included in each replicate.

Total RNA was extracted from new leaf tissue $(\sim 100$ $\mathrm{mg}$ ) taken from the upper part of rice seedlings at 15 dpi using Trizol reagent according to the manufacturer's instructions (Vazyme Biotech, China). Reverse transcription polymerase chain reaction (RT-PCR) amplification of the viral RNA was carried out using a HiScript II One-Step RNA PCR kit (Dye Plus) P612-01(Vazyme Biotech), and the virus was detected using a procedure similar to a previously reported method [2]. Viruspositive plants were defined as infected, while virusnegative plants were considered to be healthy. The plants were monitored for symptoms, and yield factors were measured.

\section{Observation of symptoms and measurement of relevant indicators}

Symptoms of tested rice plants were observed, plant heights measured and symptomatic rates counted at 5, $10,15,20,25,30,45$ and 60 dpi. When $100 \%$ of healthy control plants had headed, the number of heading virusinfected plants was measured and the heading rate of the infected plants was calculated.

A SPAD-502 Plus chlorophyll meter (Minolta, Osaka, Japan) was used to determine the chlorophyll content of upper, middle and lower portions of tested rice plant leaves at $45 \mathrm{dpi}$. The average SPAD value of the three leaf parts was used as an indicator of leaf chlorophyll content [7].

At $45 \mathrm{dpi}$, the middle part of the test plant leaves $(\sim 5 \mathrm{~g})$ were collected and dried at $65^{\circ} \mathrm{C}$ for $48 \mathrm{~h}$. After pulverization, the samples were passed through 40- to 80mesh sieves and extracted with a 2:1 mixture of acetone and alcohol. After carbonization of cellulose with $72 \%$ sulfuric acid, the extract was diluted with distilled water and heated at $121^{\circ} \mathrm{C}$ for $1 \mathrm{~h}$. The hydrolysate was filtered, and cellulose, hemicellulose and lignin contents were measured using a 940 Professional IC Vario instrument. Further, the data was converted cellulose and hemicellulose content according to National Renewable Energy laboratory's standard [8].

\section{Yield loss determination}

At rice plant maturity, the following parameters were measured: the number of tillers, plant height, panicle length, effective panicle number, filled grain number, empty grain number, total grain number, single panicle weight and kernel weight.

\section{Data analysis}

The statistical software package SPSS 20.0 (IBM, Armonk, NY, USA) was used to analyze the experimental data. The data were analyzed by one-way analysis of variance (ANOVA) to check for significant differences between infected and healthy plants at $P<0.05$ and $P<$ 0.01 . Pairwise differences between different cultivars and the significant differences between infected and healthy plants in percentage were evaluated using the nonparametric Kruskal-Walli tests.

\section{Results}

\section{Characteristic symptoms}

In our three experiments, the RSMV-infected Meixiangzhan plants that we obtained were respectively $25(83.33 \%)$, 26(86.67\%) and 18(60\%); and RSMV-infected Nipponbare plants were respectively 28(93.33\%), 26(86.67\%) and 26(86.67\%); and RSMV-infected Wuyou 1179 plants were respectively $28(93.33 \%), 27(90.00 \%)$ and $22(73.33 \%)$. The infected plants were used for the observation of symptoms and measurement of relevant indicators.

Typical RSMV symptoms of plant dwarfing and striped or spotted, stiff, crinkled or even twisted leaves were observed in the three tested varieties (Fig. 1a-c). No 


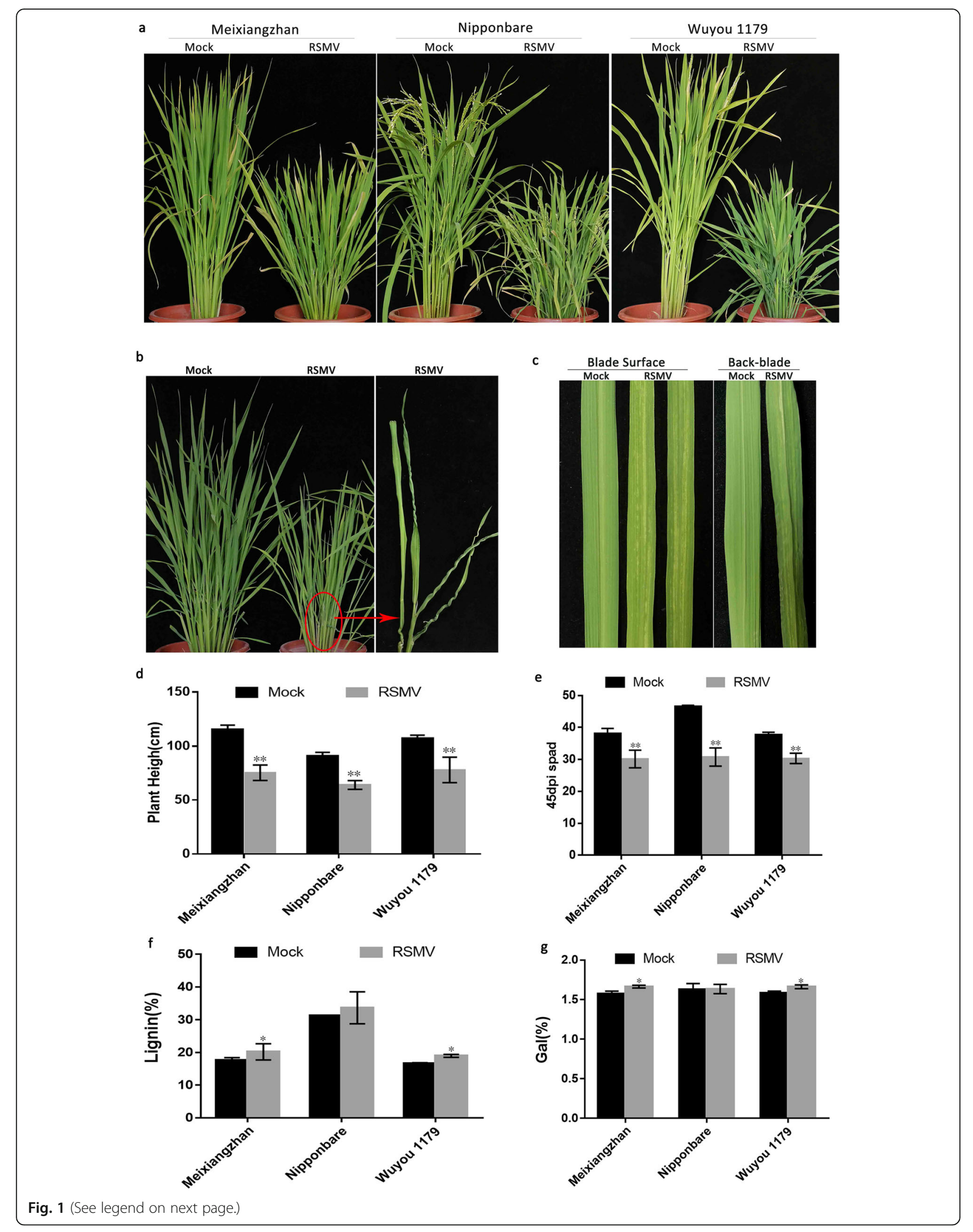


(See figure on previous page.)

Fig. 1 Typical symptoms of RSMV infection in rice. a Plant heights of three RSMV-infected varieties at 75 dpi. b Stiff, twisted leaves of RSMVinfected Wuyou 1179 at 45 dpi. c Mosaicism on leaf blade surfaces and undersides of Meixiangzhan at 45 dpi. d Plant heights of the three RSMVinfected varieties at $60 \mathrm{dpi}$. (Meixiangzhan: $\mathrm{df}=22.035, \mathrm{SD}=1.98, p<0.0001$; Nipponbare: $\mathrm{df}=28, \mathrm{SD}=1.34, p<0.0001$; Wuyou 1179: $\mathrm{df}=15.705$, $\mathrm{SD}=2.91, p<0.0001$ ) e SPAD values of the three infected varieties at $45 \mathrm{dpi}$. (Meixiangzhan: $\mathrm{df}=26.036, \mathrm{SD}=1.057, p<0.0001 ;$ Nipponbare: $\mathrm{df}=$ 17.860, $\mathrm{SD}=1.34, p<0.0001$; Wuyou 1179: $\mathrm{df}=28, \mathrm{SD}=0.86, p<0.0001) \mathbf{f}-\mathbf{g}$ Leaf lignin $(\mathbf{f})$ and galactose $(\mathbf{g})$ contents of the three infected varieties (Leaf lignin Contents: Meixiangzhan: $\mathrm{df}=1, p=0.05$; Nipponbare: $\mathrm{df}=1, p=0.513$; Wuyou 1179: $\mathrm{df}=1, p=0.05$; Leaf galactose Contents: Meixiangzhan: $\mathrm{df}=1, p=0.05$; Nipponbare: $\mathrm{df}=1, p=0.827$; Wuyou 1179: $\mathrm{df}=1, p=0.05$ ) Values in $\mathrm{d}-\mathrm{g}$ are means $\pm \mathrm{s}$. $\mathrm{d}$. $(\mathrm{d}-\mathrm{e}, n=15$ plants; $\mathrm{f}-\mathrm{g}$, $n=3$ replicates). Significant differences are indicated by asterisks: ${ }^{*}$, significant $(P<0.05)$; ${ }^{* *}$, highly significant $(P<0.01)$

significant difference in the types of symptoms was noted among varieties, but the severity of symptoms varied.

Plant heights of rice cultivars Meixiangzhan, Nipponbare and Wuyou 1179 at 75 days post infection (dpi) with RSMV were respectively $65.41,70.75$ and $72.84 \%$ of those of healthy control plants, and the infected plants displayed significant dwarfing (Fig. 1d). The three rice varieties were dwarfed to different extents after RSMV infection: Meixiangzhan exhibited the highest degree of dwarfing, followed by Nipponbare and then Wuyou 1179 (Additional file 1: Figure S1).

Leaf chlorophyll contents, as reflected by SPAD values, of the infected varieties Meixiangzhan, Nipponbare and Wuyou 1179 were reduced respectively by 20.71, 33.86 and $19.40 \%$ of those of healthy control plants at $45 \mathrm{dpi}$, thus indicating that the chlorophyll contents of infected plants were obviously decreased (Fig. 1e). The degree of reduction differed significantly among the three varieties; the highest reduction in SPAD values was in Nipponbare, followed by Meixiangzhan and then Wuyou 1179 (Additional file 2: Figure S2).

Cellulose, hemicellulose and lignin contents of plant leaves affect leaf morphology. Infection with RSMV can increase the stiffness of rice leaves, a change that is readily apparent by manual comparison of infected and healthy leaves. At $45 \mathrm{dpi}$, lignin contents of the three tested varieties were increased (Fig. 1f). Cellulose contents of Meixiangzhan and Wuyou 1179 were decreased, and the hemicellulose contents of three varieties were also decreased (Additional file 15: Table S1). Glucose contents of indica and hybrid rice varieties decreased by 9.32 and 6.87\%, respectively (Additional file 3: Figure S3). Galactose contents of the three tested varieties (Meixiangzhan, Nipponbare and Wuyou 1179 ) increased by $5.69,0.24$ and $5.01 \%$, respectively (Fig. 1g). Changes in the contents of these substances may be responsible for the stiffening of leaves.

\section{The process of characteristic symptom development}

The first disease symptom observed on RSMV-infected plants was mosaic stripes on leaves, which generally appeared at the tip of newly emerged leaves. In three repeated trials at $10 \mathrm{dpi}$, the incidence of mosaicism on the three cultivars was as follows: indica rice
Meixiangzhan, 81.82, 43.75 and 5.56\%; japonica rice Nipponbare, 56.52, 13.64 and 22.22\%; and hybrid rice Wuyou 1179, 13.04, 30.00 and 3.85\% (Fig. 2a). At 15 $\mathrm{dpi}$, the incidence of mosaicism on the three tested varieties had increased significantly, to more than $80 \%$. In the worst case, $90.91 \%$ of Meixiangzhan plants were affected. The mosaic symptoms of some infected plants later receded (Fig. 2a). As the disease developed, the proportion of mosaic leaves increased first and then decreased (Additional file 4: Figure S4). SPAD values, representing chlorophyll content, were always lower in infected plants than in healthy ones; the largest differences between infected and healthy plants were observed from 5 to $10 \mathrm{dpi}$ and 30 to $45 \mathrm{dpi}$, and the smallest difference was from 15 to $25 \mathrm{dpi}$ (Additional file 5: Figure S5).

Dwarfing was first observed at $15 \mathrm{dpi}$. By the end of the experiment, infected plants of the three tested varieties were approximately $80 \%$ of healthy control plants (Additional file 6: Figure S6). With the development of the disease, the dwarfing phenotype became increasingly obvious, especially in Wuyou 1179. At $25 \mathrm{dpi}$, the heights of infected plants were less than $80 \%$ of healthy control plants. Dwarfing was most pronounced in Meixiangzhan and Nipponbare during later disease stages. At $45 \mathrm{dpi}$, heights of Meixiangzhan and Nipponbare were respectively 88.04 and $79.53 \%$ of those of healthy control plants (Additional file 6: Figure S6).

Leaf crinkling was observed from 15 to $20 \mathrm{dpi}$ in some infected plants. The emergence time of this symptom varied slightly among varieties, appearing first in Nipponbare, secondly in Meixiangzhan and finally in Wuyou 1179 (Figs. 2b and Additional file 7: Figure S7). At 20 $\mathrm{dpi}$, the incidence of leaf crinkling based on three replicates was $34.78,18.75$ and $11.11 \%$ in Meixiangzhan, $13.04,13.64$ and $11.11 \%$ in Nipponbare, and $21.74 \%$. 15.00 and $7.69 \%$ in Wuyou 1179 (Fig. 2b). At 45 dpi, the incidence of this symptom was significantly increased, reaching more than $60 \%$, with that of Nipponbare and Wuyou 1179 at or above $90 \%$ (95.45 and 90.00\%, respectively) (Fig. 2b). After an initial increase, the proportion of crinkled leaves per plant declined and then increased. As the disease developed, some leaf crinkling symptoms also receded (Additional file 8: Figure S8). 

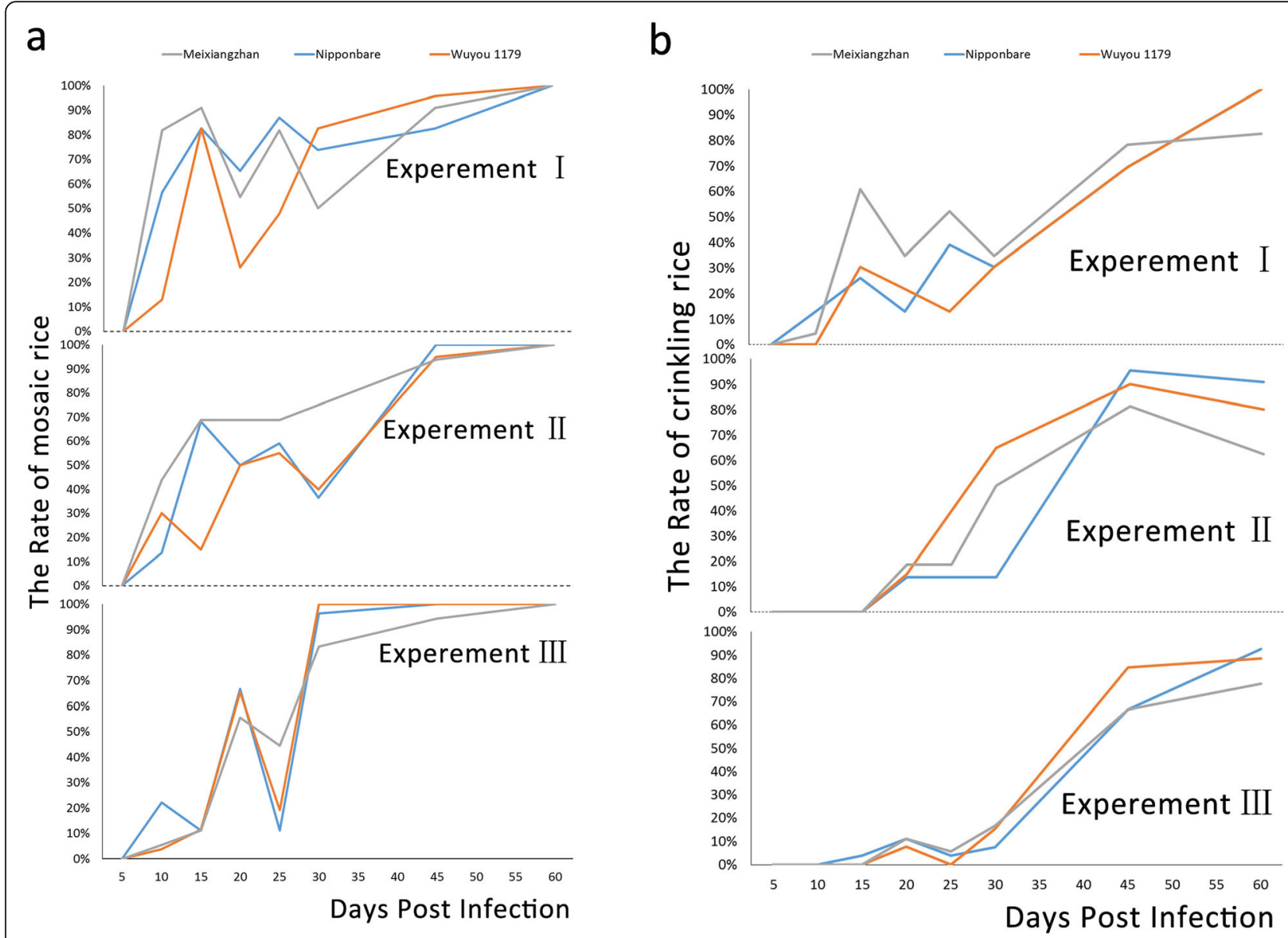

Fig. 2 Development of characteristic symptoms in three rice varieties after infection with RSMV. a-b Proportion of plants with mosaic (a) and leaf crinkling (b) symptoms

\section{Symptoms associated with rice yield and yield losses}

The number of tillers in the three RSMV-infected varieties increased significantly: by $40.00 \%$ in Meixiangzhan, $47.50 \%$ in Nipponbare and $55.56 \%$ in Wuyou 1179 (Figs. 3a-b and Additional file 9: Figure S9). Among the three varieties, these differences were not significant. In infected plants, heading time was significantly delayed, and heading was incomplete (Fig. 3c). When $100 \%$ of healthy control plants had undergone heading, the heading incidence of Meixiangzhan was $42.86 \%$ (Experiment II) and $72.73 \%$ (Experiment III); that of Nipponbare was only $84.38 \%$ (II) and $58.33 \%$ (III), while that of Wuyou 1179 was $34.78 \%$ (II) and $5.26 \%$ (III) (Table 1).

As the number of tillers increased, the number of rice panicles in RSMV-infected plants also increased. Average numbers of panicles per plant in the three tested varieties were 150.57\% (Meixiangzhan), 127.45\% (Nipponbare) and $162.29 \%$ (Wuyou 1179) of those of healthy plants (Figs. 4b and Additional file 10: Figure S10). In contrast to the increase in panicle numbers, panicle lengths of infected plants were significantly decreased, being only $65.47 \%$ (Meixiangzhan), 78.36\% (Nipponbare) and 59.08\% (Wuyou 1179) of those of healthy ones (Additional file 11: Figure S11). In addition, the panicles of Meixiangzhan and Wuyou 1179 were arranged in short clusters (Fig. 4a).

Single panicle weights of the three RSMV-infected varieties were $10.03 \mathrm{~g}$ (Maixiangzhan), $32.89 \mathrm{~g}$ (Nipponbare) and $33.58 \mathrm{~g}$ (Wuyou 1179), which were only 14.58, 74.47 , and $47.58 \%$ of those of healthy controls. This difference was extremely significant (Fig. 4c). Among the three varieties, Meixiangzhan exhibited the most drastic reduction, up to $85.42 \%$, while the reductions in Wuyou 1179 and Nipponbare were 52.43 and 25.53\%, respectively. Among Meixiangzhan and Nipponbare, the difference was significant (Additional file 12: Figure S12). Compared with the control, seed setting rates of the diseased rice plantlets were also significantly reduced, by 94.86\% (Maixiangzhan), 49.32\% (Nipponbare) and $53.06 \%$ (Wuyou 1179). The differences among the varieties were significant (Figs. 4d and Additional file 13: Figure S13). 


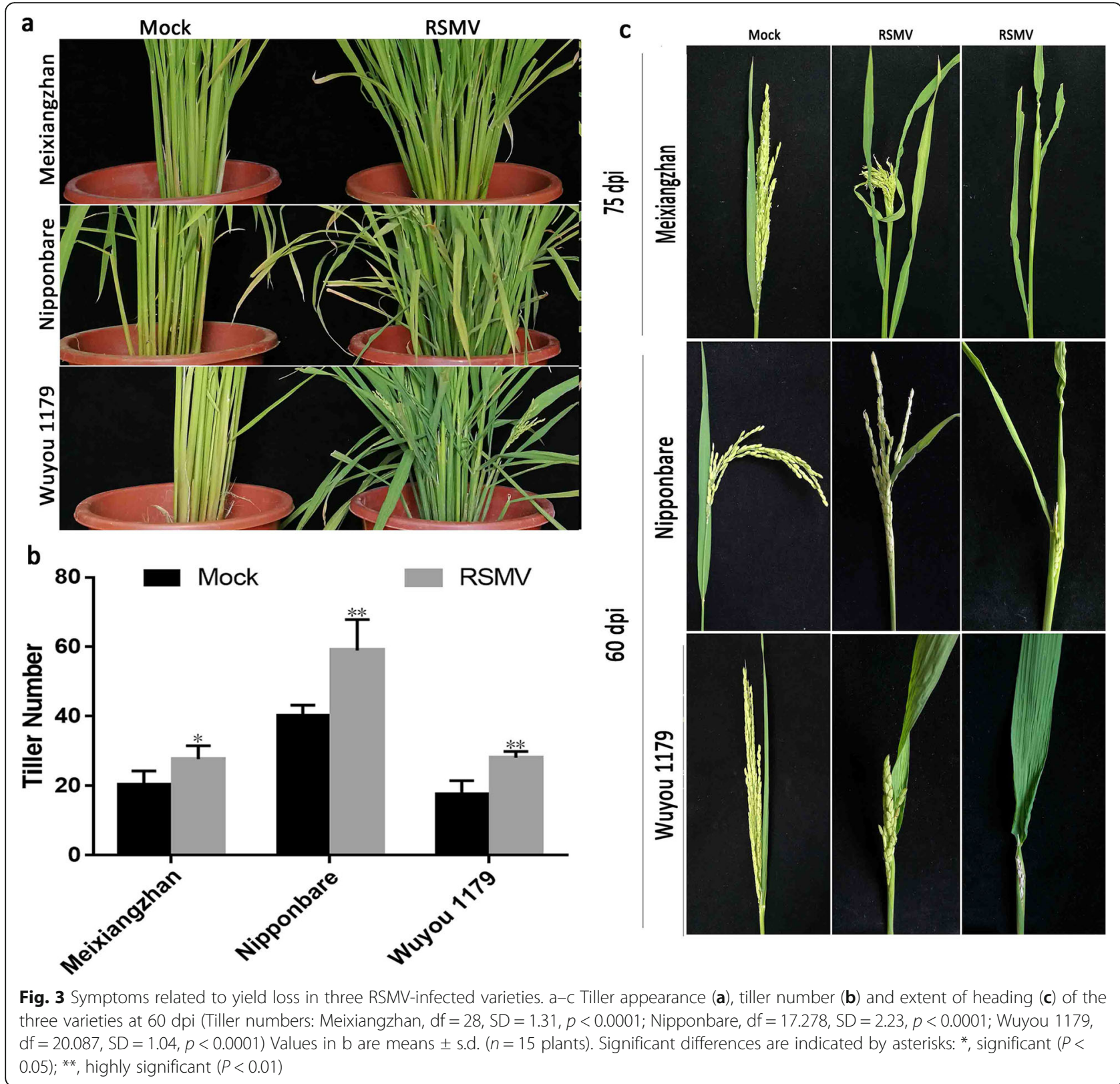

The 1000-kernel weights of RSMV-infected plants were significantly reduced: to $68.44 \%$ (Maixiangzhan), $76.14 \%$ (Nipponbare) and 74.35\% (Wuyou 1179) of those of healthy plants. The level of reduction differed significantly among varieties (Figs. 4e and Additional file 14: Figure S14).

\section{Discussion}

The three rice varieties infected with RSMV exhibited slight dwarfing, striped mosaicism, stiff, crinkled and even twisted leaves, an increased number of tillers, delayed heading, cluster-shaped shortening of panicles and mostly unfilled grains. Among these symptoms, mosaicism appeared earlier and crinkling later, with both symptoms receding in some infected plants. Yield losses due to RSMV also differed among varieties, with the most serious yield reduction observed in indica cultivar Meixiangzhan, followed by hybrid Wuyou 1179 and then japonica cultivar Nipponbare. Compared with healthy plants, infected varieties had single panicle weights, seed setting rates and 1000-kernel weights that were reduced by $85.42,94.85$ and $31.56 \%$ (Meixiangzhan); 52.43, 53.06 and 25.65\% (Wuyou 1179); and 25.53, 49.32 and $23.86 \%$ (Nipponbare), respectively.

RSMV is a recently identified, tentative new rice virus. Because published studies on the virus are limited, the symptoms of RSMV are still relatively unknown. In the present investigation, we studied the symptoms of 
Table 1 Heading characteristics of three rice varieties after infection with RSMV

\begin{tabular}{|c|c|c|c|c|c|}
\hline Varieties & Days post infection & Treatment & Number of heading plants & Number of all plants & The heading incidence (\%) \\
\hline \multirow[t]{4}{*}{ Meixiangzhan } & 70dpi & CK & 6 & 6 & 100.00 \\
\hline & & RSMV & 6 & 14 & 42.86 \\
\hline & $75 \mathrm{dpi}$ & CK & 22 & 22 & 100.00 \\
\hline & & RSMV & 16 & 22 & 72.73 \\
\hline \multirow[t]{4}{*}{ Nipponbare } & 50dpi & CK & 14 & 14 & 100.00 \\
\hline & & RSMV & 27 & 32 & 84.38 \\
\hline & 55dpi & CK & 10 & 10 & 100.00 \\
\hline & & RSMV & 14 & 24 & 58.33 \\
\hline \multirow[t]{4}{*}{ Wuyou 1179} & 60dpi & CK & 12 & 12 & 100.00 \\
\hline & & RSMV & 8 & 23 & 34.78 \\
\hline & 70dpi & CK & 6 & 6 & 100.00 \\
\hline & & RSMV & 1 & 19 & 5.26 \\
\hline
\end{tabular}

RSMV-infected rice by simulating field environmental conditions, with the goal of providing a biological basis for a follow-up theoretical study of RSMV. According to our research, the symptoms of RSMV can be clearly recognized in the field, thus providing a reference for early identification of the disease and timely prevention and control measures according to the disease situation.

Although the leaf stripe mosaic symptom of RSMVinfected plants is similar to that of rice infected with rice stripe virus (RSV, transmitted by the small brown planthopper (SBPH; Laodelphax striatellus), Terthron albovittatum, Unkanodes sapporonus and Unkanodes albifascia), some characteristic differences exist. At the early infection phase, both viruses cause mottled stripes on leaves of infected rice; at the later infection stage, however, significant differences are observed. In particular, the mosaic symptoms of RSMV gradually diminish or even disappear, whereas mottled leaves infected with RSV whiten or even wither [9]. In addition, RSVinfected leaves exhibit a drooping phenotype, while RSMV-infected rice has erect leaves that are more rigid than those of healthy plants. This latter characteristic is similar to the symptoms of rice dwarf virus (RDV, transmitted in a persistent manner by Nephotettix cincticeps, $N$. nigropictus, Recilia dorsalis, and some other Nephotettix spp.), rice gall dwarf virus (RGDV, transmitted in a persistent manner by $N$. cincticeps, $N$. nigropictus, Recilia dorsalis, and some other Nephotettix spp.), rice blackstreaked dwarf virus (RBSDV, transmitted in a persistent manner primarily by the planthopper, Laodelphax striatellus, $U$. sapporonus and Ribautodelphax albifascia) and southern rice black-streaked dwarf virus (SRBSDV, transmitted by Sogatella furcifera in a persistent propagative manner) $[3,5,6,10]$. Leaf tensile strength and stiffness, which mainly depend on cellulose, hemicellulose and lignin contents, are also related to hormonal changes in plants [11-13]. In our study, cellulose, hemicellulose and lignin contents of leaves of RSMV-infected plants changed significantly. The increased tiller number symptom of RSMV is comparable to that of rice bunchy stunt virus (RBSV, transmitted in a persistent manner by Nephotettix cincticeps and $N$. virescens), RDV and rice grass stunt virus (RGSV, transmitted in a persistent manner by the brown planthopper Nilaparvata lugens and by two other Nilaparvata spp.) and differs from that of RGDV and rice yellow stunt virus (RYSV, transmitted in a persistent manner by Nephotettix cincticeps, $N$. nigropictus, and $N$. virescens) $[3,14-18]$. Similar to the effects of many rice virus diseases, RSMV-infected plants exhibit dwarfing; however, the degree of dwarfing induced by RSMV is far less than that from SRBSDV, RGDV, RBSDV, RDV, rice ragged stunt virus (RRSV, transmitted in a persistent manner by the brown planthopper, Nilaparvata lugens) and RYSV but is similar to that caused by RSV [6, 19-23].

The mosaicism and crinkling symptoms observed in RSMV-infected leaves may recede, which is similar to the progression of leaf yellowing caused by RYSV [24, 25]. Both viruses are species in the Rhabdoviridae family, the former in the genus Cytorhabdovirus and the latter in Nucleorhabdovirus. More interestingly, leaf symptoms caused by barely yellow striate mosaic virus (BYSMV; genus Cytorhabdovirus, family Rhabdoviridae) also recede [26, 27]. Whether recession is a common feature of Rhabdoviridae-caused diseases thus deserves further study [28-30].

Rice virus diseases have the characteristics of burstiness and destructiveness, which cause intermittent disasters in eastern and southeastern Asia. For example, RSV and RBSDV transmitted by the small brown planthopper Laodelphax striatellus caused serious damage to rice production in the $1960 \mathrm{~s}$ and 2000s [3, 10, 31-35], and RDV and RYSV transmitted 

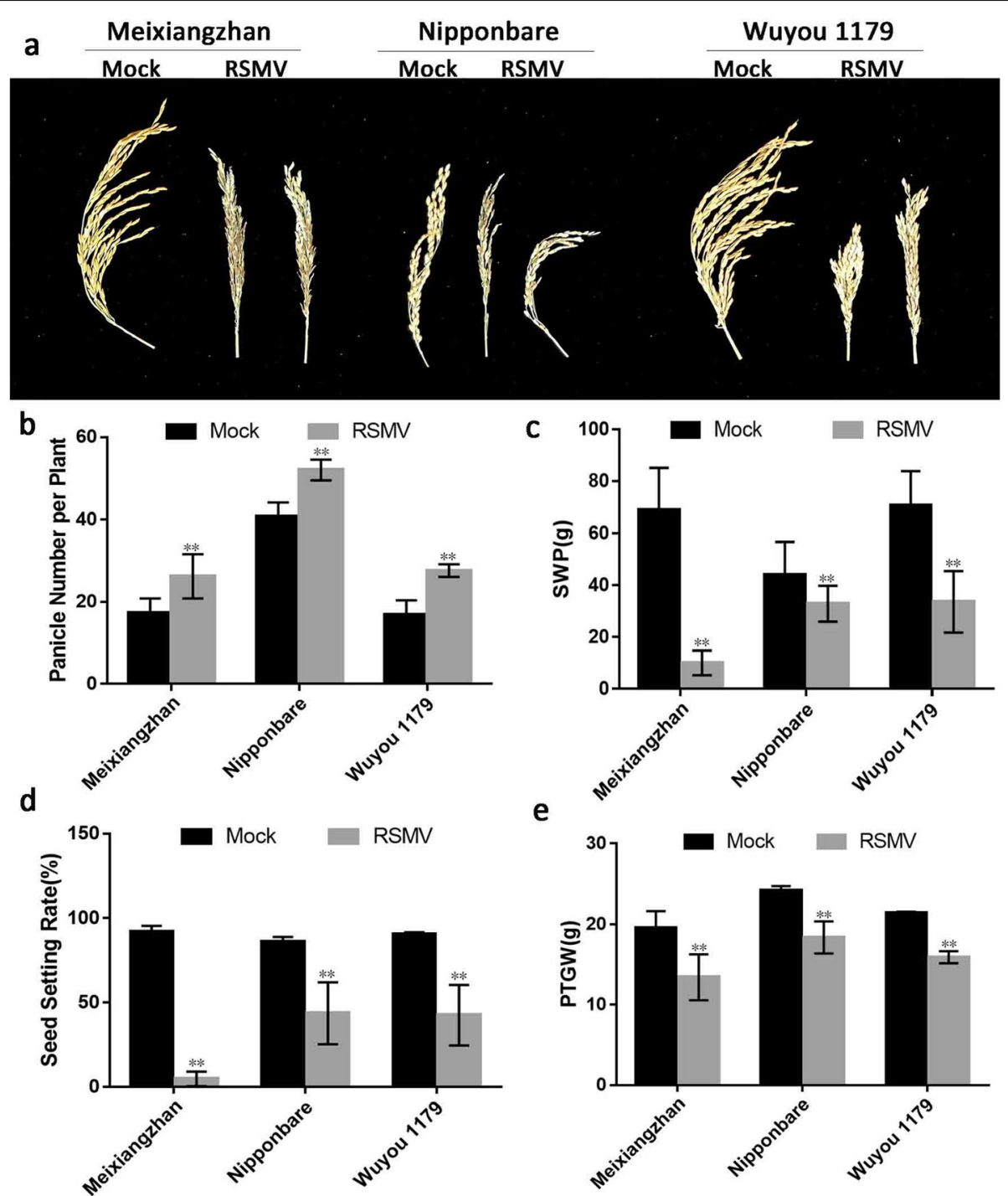

e

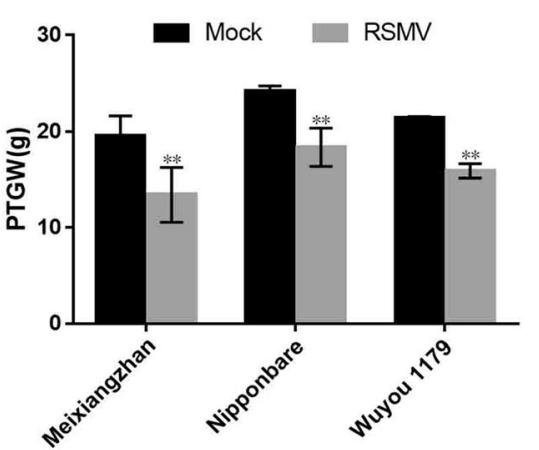

Fig. 4 Yield measurements of three RSMV-infected rice varieties. a Ripened panicles. b Panicle number per plants (Meixiangzhan: $\mathrm{df}=23.848$, $\mathrm{SD}=1.52, p<0.0001$; Nipponbare: $\mathrm{df}=28, \mathrm{SD}=1.01, p<0.0001$; Wuyou 1179: $\mathrm{df}=18.910, \mathrm{SD}=0.93, p<0.0001)$. c Spike weight per plant (Meixiangzhan: $\mathrm{df}=16.348, \mathrm{SD}=4.08, p<0.0001$; Nipponbare: $\mathrm{df}=21.835, \mathrm{SD}=3.43, p=0.003<0.01$; Wuyou 1179: $\mathrm{df}=28, \mathrm{SD}=4.26, p<0.0001$ ). $\mathbf{d}$ Seed setting rate $(\mathrm{df}=1, p=0.009<0.01)$. e 1000-kernel weight (Meixiangzhan: $\mathrm{df}=28, \mathrm{SD}=0.84, p<0.0001$; Nipponbare: $\mathrm{df}=28, \mathrm{SD}=0.49, p<$ 0.0001; Wuyou 1179: $\mathrm{df}=15.270, \mathrm{SD}=0.18, p<0.0001$ ). Values in b-e are means \pm s.d. (b-e, $n=15$ plants). Significant differences are indicated by asterisks: *, significant $(P<0.05) ;{ }^{*}$, highly significant $(P<0.01)$

by leafhoppers in the 1980 s are widespread in Vietnam, China and Japan [3]. Since 2009, SRBSDV has rapidly spread and has caused serious rice losses in northern Vietnam and southern China [36]. RSMV is transmitted by the leafhopper $R$. dorsalis in a persistent-propagative manner [5]. Since its discovery in 2015, the virus has spread rapidly in southern China [35]. More intense disease monitoring is thus needed. The progression of disease symptoms revealed in our study provide useful information for disease field investigations.

\section{Conclusions}

RSMV-infected plants exhibited slight dwarfing, striped mosaicism, stiff, crinkled or even twisted leaves, an increased number of tillers, delayed heading, cluster-shaped shortening of panicles and mostly unfilled grains. Among these symptoms, mosaicism appeared earlier and crinkling later, with both symptoms later receding in some infected plants. Yield losses due to RSMV also differed among varieties. Indica rice (cv. Meixiangzhan) experienced the most drastic yield reduction, followed by hybrid indica rice (cv. Wuyou 
1179 ) and then japonica (cv. Nipponbare). The results of this study provide basic data for field investigations, the formulation of prevention and control strategies and further study of the pathogenesis of RSMV.

\section{Supplementary information}

Supplementary information accompanies this paper at https://doi.org/10. 1186/s12985-019-1240-7.

\section{Additional file 1: Figure S1. Degree of dwarfing in three RSMV-} infected rice varieties.

Additional file 2: Figure S2. Percentage decrease in SPAD values of three RSMV-infected rice varieties.

Additional file 3: Figure S3. Glucose contents of three RSMV-infected rice varieties.

Additional file 4: Figure S4. Rates of leaf mosaicism of three RSMVinfected rice varieties.

Additional file 5: Figure S5. SPAD values of three RSMV-infected rice varieties.

Additional file 6: Figure S6. Plant heights of three RSMV-infected rice varieties.

Additional file 7: Figure S7. Leaves of three RSMV-infected rice varieties exhibiting crinkled and twisted phenotypes at different infection stages.

Additional file 8: Figure S8. Percentages of crinkled leaves of three RSMV-infected rice varieties.

Additional file 9: Figure S9. Percentage increase in tiller number of three RSMV-infected rice varieties. Error bars represent standard deviations.

Additional file 10: Figure S10. Percentage increase in the effective panicle number of three RSMV-infected rice varieties.

Additional file 11: Figure S11. Percentage reduction in panicle lengths of three RSMV-infected rice varieties.

Additional file 12: Figure S12. Percentage decrease in the single panicle weight per plant of three RSMV-infected rice varieties.

Additional file 13: Figure S13. Percentage decrease in seed setting rates of three RSMV-infected rice varieties.

Additional file 14: Figure S14. Percentage decrease in the 1000-kernel weight of three RSMV-infected rice varieties.

Additional file 15: Table S1. Contents (\%) of compounds related to leaf stiffness in three RSMV-infected rice varieties.

\section{Abbreviations}

BYSMV: barely yellow striate mosaic virus; dpi: day post inoculation.; RBSDV: Rice black-streaked dwarf virus; RBSV: Rice bunchy stunt virus; RDV: Rice dwarf virus; RGDV: Rice gall dwarf virus; RGSV: Rice grass stunt virus; RRSV: Rice ragged stunt virus; RRSV: Rice ragged stunt virus; RSMV: Rice stripe mosaic virus; RSV: Rice stripe virus; RT-PCR: Reverse transcription polymerase chain reaction; RYSV: Rice yellow stunt virus; SRBSDV: Southern rice black-streaked dwarf virus

\section{Acknowledgments}

We are grateful to Prof. Aimin Wu and Mr. Chen Chen (College of Forestry and Landscape Architechture, South China Agricultural University) for assistance in measuring the content of cellulose, hemicellulose and lignin. And we thank Jingxian Xue for her excellent work in growth chamber and lab maintenance.

\section{Authors' contributions}

GZ conceived and designed the experiments and revised the manuscript. SC and WL performed the experiments, analyzed the data, and wrote the paper. HX, BC and TZ collected the samples. All authors read and approved the final manuscript.

\section{Funding}

This research was supported by the National Key R\&D Program of China (2018YFD0200305 and 2016YFD0300700).

\section{Availability of data and materials}

Not applicable.

\section{Ethics approval and consent to participate}

Not applicable.

\section{Consent for publication}

Not applicable.

\section{Competing interests}

The authors declare that they have no competing interests.

Received: 19 July 2019 Accepted: 10 October 2019

Published online: 27 November 2019

References

1. Uehara-Ichiki T, Shiba T, Matsukura K, Ueno T, Hirae M, Sasaya T. Detection and diagnosis of rice-infecting viruses. Front Microbiol. 2013;4. https://doi. org/10.3389/fmicb.2013.00289.

2. Yang X, Huang J, Liu C, Chen B, Zhang T, Zhou G. Rice stripe mosaic virus, a novel Cytorhabdovirus infecting rice via leafhopper transmission. Front Microbiol. 2016;7:2140. https://doi.org/10.3389/fmicb.2016.02140.

3. Hibino H. Biology and epidemiology of rice viruses. Annu Rev Phytopathol. 1996;34:249-74. https://doi.org/10.1146/annurev.phyto.34.1.249.

4. Yang $X$, Lv K, Wang M, Zhou G. Investigation of viruses infecting rice in southern China using a multiplex RT-PCR assay. Crop Prot. 2017;91:8-12. https://doi.org/10.1016/..cropro.2016.09.012.

5. Yang X, Zhang T, Chen B, Zhou G. Transmission biology of rice stripe mosaic virus by an efficient insect vector Recilia dorsalis (Hemiptera: Cicadellidae). Front Microbiol. 2017;8. https://doi.org/10.3389/fmicb.2017. 02457.

6. Jin L, Qin Q, Wang Y, Pu Y, Liu L, Wen X, Ji S, Wu J, Wei C, Ding B, Li Y. Rice dwarf virus $P 2$ protein hijacks auxin signaling by directly targeting the rice OsIAA10 protein, enhancing viral infection and disease development. PLoS Pathog. 2016;12. https://doi.org/10.1371/journal.ppat.1005847.

7. Yang H, Li J, Yang J, Wang H, Zou J, He J. Effects of nitrogen application rate and leaf age on the distribution pattern of leaf SPAD readings in the rice canopy. PLoS One. 2014:9e88421. https://doi.org/10.1371/journal.pone. 0088421.

8. Ibáñez AB, Bauer S. Downscaled method using glass microfiber filters for the determination of Klason lignin and structural carbohydrates. Biomass Bioenergy. 2014;68:75-81. https://doi.org/10.1016/j.biombioe.2014.06.013.

9. Satoh K, Kondoh H, Sasaya T, Shimizu T, Choi IR, Omura T, Kikuchi S. Selective modification of rice (Oryza sativa) gene expression by rice stripe virus infection. J Gen Virol. 2009;91:294-305. https://doi.org/10.1099/vir.0. 015990-0

10. Lv MF, Xie L, Wang HF, Wang HD, Chen JP, Zhang HM. Biology of southern rice black-streaked dwarf virus: a novel fijivirus emerging in East Asia. Plant Pathol. 2017;66:515-21. https://doi.org/10.1111/ppa.12630.

11. Shi R, Wang JP, Lin $Y$, Li Q, Sun $Y$, Chen $H$, Sederoff RR, Chiang VL. Tissue and cell-type co-expression networks of transcription factors and wood component genes in Populus trichocarpa. Planta. 2017;245:927-38. https:// doi.org/10.1007/s00425-016-2640-1.

12. Napoleao TA, Soares G, Vital CE, Bastos C, Castro R, Loureiro ME, Giordano A. Methyl jasmonate and salicylic acid are able to modify cell wall but only salicylic acid alters biomass digestibility in the model grass Brachypodium distachyon. Plant Sci. 2017;263:46-54. https://doi.org/10.1016/j.plantsci.2017. 06.014 .

13. Angeles G, Lascurain M, Davalos-Sotelo R, Paula Zarate-Morales R, OrtegaEscalona F. Anatomical and physical changes in leaves during production of tamales. Am J Bot. 2013;100:1509-21. https://doi.org/10.3732/ajb.1200578.

14. Hiraguri A, Hibino H, Hayashi T, Shimizu T, Uehara-Ichiki T, Omura T, Sasaya $\mathrm{T}$. Complete sequence analysis of rice transitory yellowing virus and its comparison to rice yellow stunt virus. Arch Virol. 2010;155:243-5. https://doi. org/10.1007/s00705-009-0557-8.

15. Zhang H, Ge Y, Wang M, Liu J, Si H, Zhang L, Liang G, Gu M, Tang S. Mapping QTLs conferring resistance to rice black-streaked dwarf disease in 
rice (Oryza sativa L). Euphytica. 2016;212:323-30. https://doi.org/10.1007/ s00122-012-1871-1.

16. Satoh K, Yoneyama K, Kondoh H, Shimizu T, Sasaya T, Choi I, Yoneyama K, Omura T, Kikuchi S. Relationship between gene responses and symptoms induced by Rice grassy stunt virus. Front Microbiol. 2013;4. https://doi.org/ 10.3389/fmicb.2013.00313.

17. Satoh K, Shimizu T, Kondoh H, Hiraguri A, Sasaya T, Choi IR, Omura T, Kikuchi S. Relationship between symptoms and gene expression induced by the infection of three strains of Rice dwarf virus. PLoS One. 2011;6:e18094. https://doi.org/10.1371/journal.pone.0018094.

18. Moriyasu Y, Ishikawa K, Kikuchi A, Imanishi S, Tomita S, Akutsu K, Omura T. Sequence analysis of Pns11, a nonstructural protein of rice gall dwarf virus, and its expression and detection in infected rice plants and vector insects. Virus Genes. 2000;20:237-41.

19. Kim K, Choi D, Kim SM, Kwak DY, Choi J, Lee S, Lee BC, Hwang D, Hwang I. A systems approach for identifying resistance factors to Rice stripe virus. Mol Plant-Microbe Interact. 2012;25:534-45. https://doi.org/10.1094/MPMI11-11-0282.

20. Huang R, Li Y, Tang G, Hui S, Yang Z, Zhao J, Liu H, Cao J, Yuan M. Dynamic phytohormone profiling of rice upon rice black-streaked dwarf virus invasion. J Plant Physiol. 2018;228:92-100. https://doi.org/10.1016/j.jplph. 2018.06.001.

21. Nuruzzaman M, Sharoni AM, Satoh K, Karim MR, Harikrishna JA, Shimizu T, Sasaya T, Omura T, Haque MA, Hasan SMZ, et al. NAC transcription factor family genes are differentially expressed in rice during infections with Rice dwarf virus, Rice black-streaked dwarf virus, Rice grassy stunt virus, Rice ragged stunt virus, and Rice transitory yellowing virus. Front Plant Sci. 2015; 6. https://doi.org/10.3389/fpls.2015.00676.

22. Shen W, Ruan X, Li X, Zhao Q, Li H. RNA silencing suppressor Pns11 of rice gall dwarf virus induces virus-like symptoms in transgenic rice. Arch Virol. 2012;157:1531-9. https://doi.org/10.1007/s00705-012-1339-2.

23. Towata T, Matsukura K, Sanada-Morimura S, Matsumura M. Varietal differences in ovicidal response to the white-backed planthopper Sogatella furcifera (Hemiptera: Delphacidae) and susceptibility to southern rice blackstreaked dwarf virus in rice. Appl Entomol Zool. 2017;52:615-21. https://doi. org/10.1007/s13355-017-0515-y.

24. Huang Y. Discussion on the occurrence and control countermeasures of rice yellow dwarf virus. J Guangxi Agric. 2015;30:15-7. https://doi.org/10. 16872/j.cnki.1671-4652.1983.04.008 (in Chinese).

25. Fan $\mathrm{H}$, Fei W. Epidemic conditions and control of rice yellow dwarf disease in Guangdong. J S Chin Agric Coll. 1980:1-15 (in Chinese).

26. Li Q, Wang Z. Barley virus disease (continued). J Yangzhou Unive (Agric Life Sci Ed). 1983:37-43. https://doi.org/10.16872/j.cnki.1671-4652.1983.04.008 (in (hinese).

27. Plant Pathology Teaching and Research Group in Agricultural College of Shihezi University. Study on barley stripe mosaic disease. Plant Quarantine. 1982:6-11. https://doi.org/10.19662/j.cnki.issn1005-2755.1982.04.003 (in Chinese).

28. Bandyopadhyay A, Kopperud K, Anderson G, Martin K, Goodin M. An integrated protein localization and interaction map for potato yellow dwarf virus, type species of the genus Nucleorhabdovirus. Virology. 2010;402:61-71. https://doi.org/10.1016/j.virol.2010.03.013.

29. Gaafar YZA, Richert-Pöggeler KR, Maaß C, Vetten H, Ziebell H. Characterisation of a novel nucleorhabdovirus infecting alfalfa (Medicago sativa). Virol J. 2019;16. https://doi.org/10.1186/s12985-019-1147-3.

30. Higashi CHV, Brewbaker JL, Bressan A. Influence of the corn resistance gene $M v$ on the fitness of Peregrinus maidis (Hemiptera: Delphacidae) and on the transmission of maize mosaic virus (Rhabdoviridae: Nucleorhabdovirus). J Econ Entomol. 2013;106:1878-86. https://doi.org/10.1603/EC12497.

31. Reinke R, Kim S, Kim B. Developing japonica rice introgression lines with multiple resistance genes for brown planthopper, bacterial blight, rice blast, and rice stripe virus using molecular breeding. Mol Gen Genomics. 2018. https://doi.org/10.1007/s00438-018-1470-1.

32. Wang F, Li W, Zhu J, Fan F, Wang J, Zhong W, Wang M, Liu Q, Zhu Q, Zhou $\mathrm{T}$, et al. Hairpin RNA targeting multiple viral genes confers strong resistance to rice black-streaked dwarf virus. Int J Mol Sci. 2016;17:705. https://doi.org/ 10.3390/ijms17050705.

33. Zhang H, Ge Y, Wang M, Liu J, Si H, Zhang L, Liang G, Gu M, Tang S. Mapping QTLs conferring resistance to rice black-streaked dwarf disease in rice (Oryza sativa L). Euphytica. 2016;212:323-30. https://doi.org/10.1007/ s10681-016-1782-3.
34. Shiba T, Hirae M, Hayano-Saito Y, Ohto Y, Uematsu H, Sugiyama A, Okuda M. Spread and yield loss mechanisms of rice stripe disease in rice paddies, Field Crop Res. 2018;217:211-7. https://doi.org/10.1016/j.fcr.2017.12.002.

35. Yang X, Chen B, Zhang T, Li Z, Xu C, Zhou G. Geographic distribution and genetic diversity of Rice stripe mosaic virus in southern China. Front Microbiol. 2018;9. https://doi.org/10.3389/fmicb.2018.03068.

36. Zhou G, Xu D, Xu D, Zhang M. Southern rice black-streaked dwarf virus: a white-backed planthopper-transmitted fijivirus threatening rice production in Asia. Front Microbiol. 2013;4. https://doi.org/10.3389/fmicb.2013.00270.

\section{Publisher's Note}

Springer Nature remains neutral with regard to jurisdictional claims in published maps and institutional affiliations.
Ready to submit your research? Choose BMC and benefit from:

- fast, convenient online submission

- thorough peer review by experienced researchers in your field

- rapid publication on acceptance

- support for research data, including large and complex data types

- gold Open Access which fosters wider collaboration and increased citations

- maximum visibility for your research: over $100 \mathrm{M}$ website views per year

At BMC, research is always in progress.

Learn more biomedcentral.com/submissions 